\title{
PENGARUH PENERAPAN CORPORATE SOCIAL RESPONSIBILITY (CSR) TERHADAP CITRA MEREK, KEPERCAYAAN MEREK DAN LOYALITAS MEREK (Survei pada Masyarakat Sekitar PT. Tirta Investama, Desa Keboncandi, Kecamatan Gondang Wetan, Kabupaten Pasuruan)
}

\author{
Jesi Trilia Sovani, Achmad Fauzi Dh, Zainul Arifin \\ Universitas Brawijaya, Malang, Jawa Timur, Indonesia \\ Email : : jesitrilia.sovani@gmail.com achmad.fauzidh@gmail.com zainul_fia@ub.ac.id
}

\begin{abstract}
This study aims to empirically study the effect of variable Corporate Social Responsibility (CSR) to the Brand Image, Brand Trust and Brand Loyalty. The samples used in this study 116 respondents using Accidental Sampling. Respondents are society around village Keboncandi and acquire CSR PT. Tirta Investama, Using Aqua Danone products and Making a purchase at least 3 times during the last six months. The results showed that Corporate Social Responsibility (CSR) have significant effect toward Brand Image. Corporate Social Responsibility (CSR) have significant effect toward Brand Trust. Corporate Social Responsibility (CSR) have significant effect toward Brand Loyalty. Brand image have significant effect toward Brand Trust. Brand Image have significant effect toward Brand Loyalty. Brand Trust have significant effect toward Brand Loyalty.
\end{abstract}

Keywords: Corporate Social Responsibility (CSR), Brand Image, Brand Trust, Brand Loyalty

\begin{abstract}
ABSTRAK
Penelitian ini bertujuan untuk mempelajari secara empirik pengaruh dari variabel Corporate Social Responsibility (CSR) terhadap Citra Merek, Kepercayaan Merek dan Loyalitas Merek. Jumlah sampel yang digunakan dalam penelitian ini 116 orang responden dengan menggunakan Accidental Sampling. Respondennya merupakan masyarakat sekitar Desa Keboncandi yang mengetahui dan memperoleh CSR PT. Tirta Investama, Menggunakan produk Aqua Danone dan Melakukan pembelian minimal 3 kali selama enam bulan terakhir. Hasil penelitian menunjukkan bahwa Corporate Social Responsibility (CSR) berpengaruh signifikan terhadap Citra Merek. Corporate Social Responsibility (CSR) berpengaruh signifikan terhadap Kepercayaan Merek. Corporate Social Responsibility (CSR) berpengaruh signifikan terhadap Loyalitas Merek. Citra Merek berpengaruh signifikan terhadap Kepercayaan Merek. Citra Merek berpengaruh signifikan terhadap Loyalitas Merek. Kepercayaan Merek berpengaruh signifikan terhadap Loyalitas Merek.
\end{abstract}

Kata Kunci: Corporate Social Responsibility (CSR), Citra Merek, Kepercayaan Merek, Loyalitas Merek 
PENDAHULUAN

Konsep Corporate Social
Responsibility pertimbangan perusahaan dalam aktivitas bisnisnya. Perusahaan telah menyadari bahwa pentingnya peran CSR dan harus dilakukan oleh perusahaan sebagai bentuk kepedulian terhadap para pemangku kepentingan (stakeholder). Beberapa penelitian menunjukkan bahwa CSR dan pengembangan hubungan konstruktif dengan stakeholder turut menentukan keberhasilan perusahaan dalam jangka panjang (Rachman et al., 2011 h. 9). Adanya penerapan CSR untuk kurun waktu jangka panjang tentu akan mendapatkan keuntungan dalam bentuk kepercayaan dari pemangku kepentingan terhadap perusahaan. Di mana penerapan CSR tidak hanya dipandang sebagai "cost" melainkan sebagai investasi jangka panjang bagi perusahaan.

Penerapan CSR penting dilakukan oleh tiap perusahaan terkait munculnya sebuah konsep "Sustainable Development" yang dirumuskan oleh World Comission on Environment and Development, sebagai: "Development that meets the needs of the present withoutcompromising the ability of future generations to meet their own needs (Sarviya and $\mathrm{Wu}, 2014$ ). Dampak yang ditimbulkan dengan adanya penerimaan konsep CSR ke dalam SD maka seluruh kegiataan perusahaan yang berkaitan dengan Ekonomi, Sosial dan Lingkungan harus dilaporkan dalam Sustainability Report tahunan perusahaan. SR menjadi penilaian yang menggambarkan sejauh mana tanggung jawab sosial perusahaan terhadap para pemangku kepentingan.

Pelaksanaan CSR yang dilakukan oleh sebuah perusahan memberikan banyak manfaat diantaranya mendongkrak Citra Merek, membentuk Kepercayaan Merek dan membangun Loyalitas Merek. Adapun beberapa penelitian tentang manfaat penerapan CSR menunjukkan adanya hubungan positif antara CSR dengan Citra Merek, Kepercayaan Merek dan Loyalitas Merek. Kotler and Lee (2005) mengungkapkan bahwa beberapa perusahaan percaya dengan adanya CSR dapat membuat perusahaan tersebut lebih dikenal publik karena manfaat tanggung jawab sosial memungkinkan perusahaan dapat membangun citra yang baik dan reputasi yang baik (Porter and Kramer, 2006 ; Boonpattarakan, 2012).
Penelitian selanjutnya juga menunjukkan bahwa manfaat CSR dapat membentuk Kepercayaan Merek, karena CSR dapat membantu mempengaruhi identitas merek, termasuk nilai-nilai, sifat dan tujuan (Perez et al., 2009). Sebuah merek yang mampu memberikan jaminan kualitas serta berasal dari perusahaan yang memiliki reputasi, maka konsumen akan percaya dengan pilihannya dan konsumen akan memiliki kepercayaan pada merek, menyukai merek, serta menganggap merek tersebut sebagai pilihan terbaik, sehingga kesetiaan merek lebih mudah untuk dibentuk dan perusahaan akan memiliki nama merek yang memiliki kesetiaan konsumen yang kuat, karena menurut Morgan and Hunt (1994), Kepercayaan Merek (brand trust) menentukan kesetiaan konsumen terhadap merek dan kepercayaan berpotensi menciptakan hubungan-hubungan yang bernilai tinggi.

Penerapan CSR juga berpengaruh terhadap pembentukan Loyalitas Merek. Adapun proses pembentukan loyalitas produk membutuhkan proses yang panjang, bisa melalui pembelajaran, berdasarkan informasi maupun berdasarkan pengalaman. Telah dilakukan penelitian terkait peran CSR dalam membangun Loyalitas Merek, di mana CSR dapat meningkatkan sikap positif terhadap merek serta secara signifikan meningkatkan niat pembelian merek (Wigley, 2008; Schmeltz, 2011)

Di Indonesia, program CSR ini diatur pula oleh Undang-undang nomor 40 tahun 2007 pasal 74 tentang Perseroan Terbatas (UU PT) menjelaskan bahwa:

1. Perseroan dalam menjalankan kegiatan usahanya berkaitan dengan sumber daya alam, wajib melaksanakan Tanggung Jawab Sosial dan Lingkungan.

2. Tanggung Jawab Sosial dan Lingkungan merupakan kewajiban Perseroan, dalam pelaksanaannya penting memperhatikan kepatutan dan kewajaran.

3. Perseroan yang tidak melaksanakan kewajibannya akan dikenai sanksi sesuai dengan ketentuan perundang-undangan,

4. Ketentuan Tanggung Jawab Sosial dan Lingkungan diatur oleh Peraturan Pemerintah (www.hukumonline.com).

Salah satu perusahaan di Kabupaten Pasuruan yang telah menjalankan program CSR adalah PT. Tirta Investama, di Desa 
Keboncandi, Kecamatan Gondang Wetan, Kabupaten Pasuruan. PT. Tirta Investama merupakan industri air minum dalam kemasan (AMDK) merek Aqua. Program CSR yang telah dilakukan oleh PT. Tirta Investama khususnya di Desa Keboncandi meliputi berbagai bidang yaitu di bidang Pendidikan, bidang Sosial, Pemberdayaan Masyarakat dan bidang Keagamaan/Hari Besar Nasional. Penerapan program CSR oleh PT. Tirta Investama dengan menjalin kemitraan dengan Yayasan Social Invesment Indonesia (YSII) sebagai pengelola CSR PT. Tirta Investama.

\section{LATAR BELAKANG TEORI DAN HIPOTESIS}

\section{Stakeholder Theory}

Tanggung jawab perusahaan tidak hanya sebatas pada para pemilik (shareholder) dengan indikator ekonomi (Economic Focused), tetapi mencakup pada ranah yang lebih luas yaitu terkait sosial kemasyarakatan (stakeholder) dengan indikator faktor sosial (social dimention), sehingga faktor ini yang menjadi dasar munculnya istilah tanggung jawab sosial.

Pada dasarnya, Stakeholder Theory adalah teori yang menyatakan perusahaan bukanlah entitas yang hanya beroperasi untuk kepentingan sendiri, tetapi juga harus memberikan manfaat kepada seluruh pemangku kepentingan meliputi (pemegang saham, konsumen, pemasok, pemodal dan masyarakat). Sen, Bhattacharya and Korschun (2006) menyimpulkan CSR mempengaruhi pemangku kepentingan (stakeholder) dalam pembelian merek serta memperkuat hubungan secara keseluruhan. Posisi CSR memanusiakan sebuah perusahaan atau merek, mendorong pelanggan tidak hanya suka, rasa hormat atau mengagumi tetapi sebenarnya mengidentifikasi (Bhattacharya and Sen, 2003), manfaat dari identifikasi tersebut untuk memperkuat merek, banyak dan abadi (Bergami and Bagozi, 2000: Lichtenstein et al, 2004: Sen and Bhattacharya, 2001).

\section{Corporate Social Responsibility}

Secara teoritis, CSR merupakan inti dari etika bisnis, perusahaan tidak hanya mempunyai kewajiban ekonomis dan legal kepada pemegang saham (shareholders), tetapi perusahaan juga mempunyai kewajiban terhadap pihak lain yang berkepentingan (stakeholder). Sebuah perusahaan tidak bisa hidup, beroperasi dan bertahan serta memperoleh keuntungan tanpa bantuan dari berbagai pihak. CSR lebih menunjukkan kepedulian perusahaan terhadap kepentingan pihak-pihak lain secara lebih luas (stakeholder) dari pada hanya sekedar kepentingan perusahaan itu sendiri (Azheri, 2012 h. 5). Corporate Social Responsibility juga merujuk pada hubungaan antara perusahaan dengan customer, employers, komunitas masyarakat, investor, pemerintah, supplier serta kompetitor (Sitorus dan Mangoting, 2014). Keterkaitan teori CSR dengan aktivitas perusahaan, dapat dikatakan bahwa tanggung jawab lebih merujuk pada kepedulian perusahaan terhadap kepentingan stakeholder dari pada sekedar kepentingan perusahaan tersebut.

\section{Citra Merek}

Citra Merek bagian dari representasi keseluruhaan persepsi tentang sebuah merek dan terbentuk dari informasi maupun pengalaman masa lalu mengenai merek. Memiliki Citra Merek yang baik tentu lebih memudahkan konsumen dalam melakukan pembelian. Menurut Kotler dalam Bastian (2014, h. 2), Citra Merek merupakan penglihataan dan kepercayaan yang melekat di benak konsumen. Dengan demikian, Citra Merek yang kuat dalam pikiran konsumen, dapat dengan mudah memperoleh daya tarik yang lebih besar terhadap produk, sehingga memicu konsumen untuk membeli.

\section{Kepercayaan Merek}

Kepercayaan merek berkaitan dengan kemampuan merek untuk lebih dipercaya, berdasarkan pada keyakinan konsumen tentang produk yang memenuhi nilai yang dijanjikan dan intensi merek berdasarkan pada keyakinan konsumen terkait merek. Dapat diartikan Kepercayaan Merek berkaitan dengan keyakinan konsumen akan menerima hasil yang baik dalam melakukan pembelian. Merek memiliki peranan penting bagi konsumen dan produsen. Adapun manfaat merek bagi konsumen yaitu merek bagian dari proses keputusan pembelian dan jaminan terkait kualitas. Bagi produsen, merek memiliki fungsi untuk membangun loyalitas dan hubungan berkelanjutan dengan konsumen. 


\section{Loyalitas Merek}

Loyalitas Merek berkaitan dengan ukuran hubungan antara pelanggan terhadap merek, di mana ukuran tersebut memberikan sebuah gambaran tentang mudah atau tidaknya seorang pelanggan beralih kepada merek lain. Loyalitas Merek memperlihatkan sebuah ikatan antara pelanggan dengan merek tertentu harus dilihat dengan adanya pembelian secara berulang yang dilakukan oleh pelanggan. Menurut Mowen dalam Sengkey (2015), loyalitas berdasarkan pada perilaku pembelian aktual suatu produk yang dihubungkan dengan adanya proporsi pembelian. Konsep Loyalitas Merek dalam karya (Jacoby and Kyner, dalam Odin et al. 2001) menjelaskan tentang proses keputusan konsumen dan mengusulkan enam poin yaitu non-random, Perilaku respon, Menyatakan dari waktu ke waktu, Unit pengambilan keputusan, terkait dengan satu atau lebih merek alternatif dari satu merek dan Fungsi dari proses psikologis.

Adapun Secara konseptual keterkaitan antar variabel tersebut dapat dilihat pada Gambar 1.

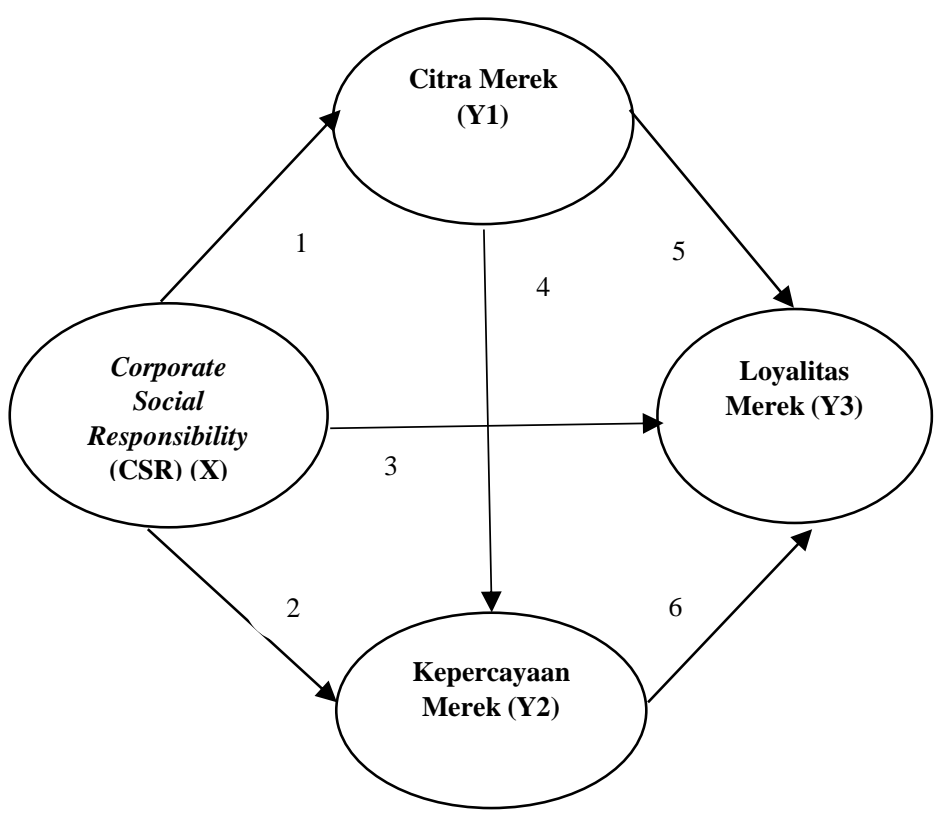

Gambar 1. Kerangka Konsep Penelitian Corporate Social Responsibility (CSR), Citra Merek, Kepercayaan Merek dan Loyalitas Merek

Sumber : Teori dan Kajian Empiris dari penelitian terdahulu
Berdasarkan model penelitian tersebut, maka hipotesis dalam penelitian ini dapat diuraikan sebagai berikut:

H1 : CSR berpengaruh signifikan terhadap Citra Merek.

Pengaruh CSR terhadap Citra Merek. Menurut Chen and Bouvain (2005), Citra Merek perusahaan memiliki keterkaitan pada peringkat Tanggung Jawab Sosial Perusahaan dan kegiatan CSR. Kontribusi perusahaan dipercaya dapat membangun Citra Merek dan Ekuitas Merek (Broon and Vrioni, 2001), Citra Merek akan meningkat melalui CSR (Latif et al., 2015). Dapat dikatakan bahwa penerapan CSRsangat menguntungkan bagi perusahaan, selain mendapat kepercayaan dari stakeholder dan juga pada peningkatan Citra Merek.

H2 : CSR berpengaruh signifikan terhadap Kepercayaan Merek.

Pengaruh CSR terhadap Kepercayaan Merek. Menurut Bevan et al. (2004), CSR merupakan dasar Kepercayaan Merek dan status dan kegiatan CSR terbukti mempengaruhi hal pokok bagi perusahaan. Menurut Barnes (2011), CSR memiliki efek yang lebih besar pada Kepercayaan Merek untuk sebuah organisasi yang bertanggung jawab secara sosial dan CSR memberikan kesempatan bagi perusahaan untuk mengembangkan hubungan bagi pemangku kepentingan serta perusahaan yang telah berpartisipasi dalam CSR.

H3 : CSR berpengaruh signifikan terhadap Loyalitas Merek.

Pengaruh CSR terhadap Loyalitas Merek. Menurut Bhattacharya and Sen (2004), perusahaan merasa dirinya dikenal dengan melakukan CSR, sehingga menjadi perhatian dalam segmen pelanggan. Menurut Fauset (2006), CSR digunakan untuk menarik hari nurani pelanggan dan keinginan perusahaan terkait CSR ini sebagai cara untuk membangun Loyalitas Merek serta mengembangkan hubungan dengan para pelanggan.

H4: Citra Merek berpengaruh signifikan terhadap Kepercayaan Merek.

Hubungan Citra Merek dengan Kepercayaan Merek, dengan memiliki Citra Merek yang kuat maka akan berpengaruh dalam pembentukan Kepercayaan Merek. Menurut Verma and Mishra (2015), Citra Merek dan 
keputusan perilaku pembelian positif membantu dalam menjaga hubungan yang kuat antara pelanggan dan merek yang meningkatkan Kepercayaan Merek.

H5 : Citra Merek berpengaruh signifikan terhadap Loyalitas Merek.

Hubungan Citra Merek dengan Loyalitas Merek. Salah satu faktor pendukung terbentuknya loyalitas yaitu Citra Merek, dengan Citra Merek yang kuat akan berpengaruh terhadap Loyalitas Merek (Latif et al., 2015). Menurut Khan (2011), Citra Merek memiliki pengaruh dalam membangun loyalitas terhadap merek. Menurut Wood (2000), deskripsi merek (Citra Merek) merupakan tolak ukur dari kekuatan merek (Loyalitas Merek). Pendapat lain, menyatakan bahwa membangun Citra Merek merupakan alat stategis yang digunakan untuk mengembangkan Loyalitas Merek (Bath and Reddy, 1998; Yoo et al. 2000). Terbentuknya Citra Merek yang kuat, maka akan menjadi pilihan konsumen untuk loyal pada merek tersebut.

H6 : Kepercayaan Merek berpengaruh signifikan terhadap Loyalitas Merek.

Hubungan Kepercayaan Merek dengan

Loyalitas Merek. Kepercayaan Merek merupakan salah satu faktor penentu dalam meningkatkan loyalitas (Aggarwal, 2014). Peran dari Kepercayaan Merek dan merek tentu berpengaruh dalam menciptakan Loyalitas Merek sebagai penentu dari Ekuitas Merek (Chaudhuri and Holbrook (2001). Menurut Morgan and Hunt (1994), Kepercayaan Merek akan berpengaruh terhadap Loyalitas Merek atau komitmen karena kepercayaan menciptakan hubungan pertukaran yang sangat dihargai, sehingga loyalitas dan komitmen menjadi dasar dari sebuah proses yang berkelanjutan dalam mempertahankan sebuah nilai serta hubungan penting yang terjalin sebagai dasar kepercayaan. Peran Kepercayaan dalam membangun dan mempertahankan Loyalitas Merek telah diteliti melalui konsumen dan situasi pembelian dalam bisnis (Cowles, 1997; Doney and Cannon, 1997; Chaudhuri and Halbrook, 2001)

\section{METODE PENELITIAN}

Jenis penelitian yang digunakan dalam penelitian ini adalah penelitian kuantitatif yang mencakup metode survei, sedangkan alasan menggunakan penelitian kuantitatif untuk meneliti sebuah populasi atau sampel tertentu, menguji hipotesis yang telah ditetapkan dan ingin mendapatkan data yang akurat.. Lokasi penelitian adalah masyarakat sekitar PT.Tirta Investama, Desa Keboncandi, Kecamatan Gondang Wetan, Kabupaten Pasuruan. Pada penelitian ini obyek yang digunakan adalah masyarakat yang bertempat tinggal di Desa Keboncandi. Adapun populasi yang dijadikan responden dalam penelitian ini harus memenuhi kriteria-kriteria di bawah ini :

a. Merupakan masyarakat yang tinggal di Desa Keboncandi.

b. Mengetahui dan memperoleh program CSR PT. Tirta Investama.

c. Menggunakan produk dari PT. Tirta Investama (Aqua Danone).

d. Melakukan pembelian minimal 3 kali selama enam bulan terakhir.

Jumlah populasi dalam penelitian ini tidak diketahui, maka dalam menentukan jumlah sampel digunakan rumus Machin and Campbell. Penentuan jumlah sampel dalam penelitian ini mengambil $r=0,30$, kemudian $\alpha$ $=0,05\left(\mathrm{Z}_{1-\alpha}=1,96\right)$ pada pengukuran dua arah, $\beta=0,05\left(Z_{1-\beta}=1,645\right)$, maka diperoleh sebanyak 116 orang responden. Dalam penelitian ini penulis mengambil sampel minimal 116 pelanggan. Penentuan responden dilakukan secara kebetulan ketemu (Accidental Sampling) pada saat dilakukan penelitian pada masyarakat sekitar PT. Tirta Investama, Desa Keboncandi. Sedangkan cara pengambilan sampel secara proporsional dalam penelitian ini, sebagai berikut:

a. Jumlah penduduk Dusun Buyutan 600 jiwa, dan hasil perhitungan sampel yang diambil secara proporsional sejumlah 33 orang responden.

b. Jumlah penduduk Dusun Keboncandi 738 jiwa, dan hasil perhitungan sampel yang diambil secara proporsional sejumlah 41 orang responden.

c. Jumlah penduduk Dusun Bangilan 114 jiwa, dan hasil perhitungan sampel yang diambil secara proporsional sejumlah 6 orang responden.

d. Jumlah penduduk Dusun Buyutan 650 
jiwa, dan hasil perhitungan sampel yang diambil secara proporsional sejumlah 36 orang responden.

\section{Metode Pengumpulan Data}

Untuk memperoleh data yang digunakan dalam penelitian ini berasal dari dua macam data yaitu sumber data primer melalui penyebaran kuesioner, dan sumber data sekunder seperti buku, jurnal, e-book, report perusahaan dan dokumen yang tersedia kantor Desa Keboncandi. Instrumen yang digunakan yaitu kuesioner untuk mengumpulkan data dari responden dan menyusun pedoman wawancara, di mana peneliti melakukan wawancara terhadap Kepala Desa Keboncandi dan Kepala Dusun untuk memperoleh data tentang program CSR yang sudah dilakukan oleh PT. Tirta Investama, serta melakukan observasi terkait bukti CSR yang pernah diterima masyarakat dan beberapa Dusun di Keboncandi. Sedangkan untuk pengukuran variabel menggunakan skala Likert.

\section{Uji Asumsi Klasik}

Tabel 1. Uji Asumsi Normalitas

\begin{tabular}{|c|c|c|c|}
\hline $\begin{array}{c}\text { Hasil Uji } \\
\text { Persamaan }\end{array}$ & $\mathbf{N}$ & $\begin{array}{c}\text { Kolmogorov- } \\
\text { Smirnov Z }\end{array}$ & $\begin{array}{c}\text { Sig. } \\
\text { (2-tailed) }\end{array}$ \\
\hline Pertama & 116 & 1.115 & 0.166 \\
\hline Kedua & 116 & 1.061 & 0.211 \\
\hline Ketiga & 116 & 1.123 & 0.161 \\
\hline \multicolumn{2}{|r}{ Hasil }
\end{tabular}

Hasil pengujian pada Tabel 1 menunjukkan probabilitas untuk persamaan pertama sebesar 0.166, persamaan kedua sebesar 0.211, dan persamaan ketiga sebesar 0.161 . Ketiga nilai tersebut $>0.05$ sehingga nilai residual data terdistribusi normal.

Tabel 2. Uji Asumsi Linieritas

\begin{tabular}{|l|c|c|c|c|}
\hline Pengaruh & $\begin{array}{c}\text { F } \\
\text { tabel }\end{array}$ & $\begin{array}{c}\text { p- } \\
\text { value }\end{array}$ & Alpha & Ket \\
\hline $\mathrm{X} \rightarrow \mathrm{Y} 1$ & 3.924 & 0.000 & 0.050 & Linier \\
\hline $\mathrm{X} \rightarrow \mathrm{Y} 2$ & 3.924 & 0.000 & 0.050 & Linier \\
\hline $\mathrm{X} \rightarrow \mathrm{Y} 3$ & 3.924 & 0.000 & 0.050 & Linier \\
\hline $\mathrm{Y} 1 \rightarrow \mathrm{Y} 2$ & 3.924 & 0.000 & 0.050 & Linier \\
\hline $\mathrm{Y} 1 \rightarrow \mathrm{Y} 3$ & 3.924 & 0.000 & 0.050 & Linier \\
\hline $\mathrm{Y} 2 \rightarrow \mathrm{Y} 3$ & 3.924 & 0.000 & 0.050 & Linier \\
\hline
\end{tabular}

Hasil uji linieritas pada Tabel 2 dengan uji kurva menunjukkan hubungan antara variabel bebas dan variabel terikat adalah linier yang ditunjukkan dari p-value masing-masing hubungan yang lebih kecil dari alpha 5\% (0.050) sehingga asumsi linieritas terpenuhi.

\section{Metode Analisis Data}

Metode analiis yang digunakan dalam penelitian ini menggunakan analisis data secara Deskriptif untuk mengungkap gambaran data yang telah dikumpulkan dari lokasi penelitian. Untuk teknik analisis yang digunakan yaitu path analysis.

\section{HASIL PENELITIAN DAN PEMBAHASAN}

Tabel 3. Analisis Jalur

\begin{tabular}{|c|c|c|c|c|c|c|}
\hline \multirow[t]{2}{*}{ Model } & \multicolumn{2}{|c|}{$\begin{array}{c}\text { Unstandardize } \\
\text { Coefficients }\end{array}$} & \multirow{2}{*}{$\begin{array}{c}\text { Standardize } \\
\text { Coefficients } \\
\text { Beta } \\
\end{array}$} & \multirow[b]{2}{*}{$\mathbf{T}$} & \multirow[b]{2}{*}{ Sig. } & \multirow[b]{2}{*}{ Keterangan } \\
\hline & B & $\begin{array}{l}\text { Std. } \\
\text { Error }\end{array}$ & & & & \\
\hline $\mathrm{X} \rightarrow \mathrm{Y} 1$ & .290 & .048 & .493 & 6.050 & .000 & Signifikan \\
\hline $\mathrm{X} \rightarrow \mathrm{Y} 2$ & .088 & .033 & .215 & 2.644 & .009 & Signifikan \\
\hline $\mathrm{X} \rightarrow \mathrm{Y} 3$ & .118 & .048 & .223 & 2.455 & .016 & Signifikan \\
\hline $\mathrm{Y} 1 \rightarrow \mathrm{Y} 2$ & .364 & .056 & .526 & 6.469 & .000 & Signifikan \\
\hline $\mathrm{Y} 1 \rightarrow \mathrm{Y} 3$ & .226 & .092 & .252 & 2.440 & .016 & Signifikan \\
\hline $\mathrm{Y} 2 \rightarrow \mathrm{Y} 3$ & .289 & .132 & .224 & 2.190 & .031 & Signifikan \\
\hline
\end{tabular}

\section{Sumber: Lampiran 10}

Ket: $\mathrm{X}=$ Corporate Social Responsibility (CSR), $\mathrm{Y} 1=$ Citra Merek, Y2 = Kepercayaan Merek,

$\mathrm{Y} 3=$ Loyalitas Merek

Tabel 4. Pengujian Pengaruh Tidak Langsung

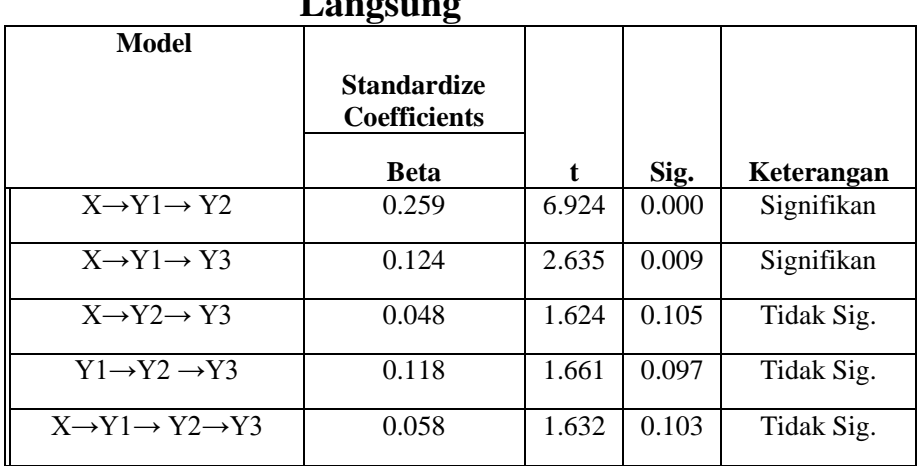

\section{Sumber: Lampiran 10}

Ket: $\mathrm{X}=$ Corporate Social Responsibility (CSR), Y1= Citra Merek, Y2 = Kepercayaan Merek, Y3 = Loyalitas Merek

\section{Pembahasan Hasil Penelitian \\ Pengaruh CSR terhadap Citra Merek}

Berdasarkan hasil analisis CSR memiliki pengaruh positif dan signifikan terhadap Citra Merek. Hal ini dapat dilihat dari t-hitung (6.050) lebih besar dari t-tabel (1.960) dan p-value (0.000) lebih kecil dari alpha 5\% (0.050). Koefisien jalur ( $\beta=0.493)$ menunjukkan bahwa CSR yang baik secara signifikan meningkatkan Citra Merek. 


\section{Pengaruh CSR terhadap Kepercayaan Merek}

Berdasarkan hasil analisis CSR memiliki pengaruh positif dan signifikan terhadap Kepercayaan Merek. Hal ini dapat dilihat dari thitung (2.644) lebih besar dari t-tabel (1.960) dan p-value (0.000) lebih kecil dari alpha 5\% (0.050). Koefisien jalur $(\beta=0.215)$ menunjukkan bahwa CSR yang baik secara signifikan meningkatkan Kepercayaan Merek.

\section{Pengaruh CSR terhadap Loyalitas Merek}

Berdasarkan hasil analisis CSR memiliki pengaruh positif dan signifikan terhadap Loyalitas Merek. Hal ini dapat dilihat dari thitung (2.455) lebih besar dari t-tabel (1.960) dan p-value (0.000) lebih kecil dari alpha 5\% (0.050). Koefisien jalur $(\beta=0.223)$ menunjukkan bahwa CSR yang baik secara signifikan meningkatkan Loyalitas Merek.

\section{Pengaruh Citra Merek terhadap Kepercayaan} Merek

Berdasarkan hasil analisis Citra Merek memiliki pengaruh positif dan signifikan terhadap Kepercayaan Merek. Hal ini dapat dilihat dari t-hitung (6.469) lebih besar dari ttabel (1.960) dan p-value (0.000) lebih kecil dari alpha 5\% (0.050). Koefisien jalur $(\beta=0.526)$ menunjukkan bahwa Citra Merek yang baik secara signifikan meningkatkan Kepercayaan Merek.

\section{Pengaruh Citra Merek terhadap Loyalitas Merek}

Berdasarkan hasil analisis Citra Merek memiliki pengaruh positif dan signifikan terhadap Loyalitas Merek. Hal ini dapat dilihat dari t-hitung (2.440) lebih besar dari t-tabel (1.960) dan p-value (0.000) lebih kecil dari alpha $5 \%$ (0.050). Koefisien jalur $(\beta=0.252)$ menunjukkan bahwa Citra Merek yang baik secara signifikan meningkatkan Loyalitas Merek.

\section{Pengaruh Kepercayaan Merek terhadap Loyalitas Merek}

Berdasarkan hasil analisis menunjukkan bahwa Kepercayaan Merek memiliki pengaruh positif dan signifikan terhadap Loyalitas Merek. Hal ini dapat dilihat dari t-hitung (2.190) lebih besar dari t-tabel (1.960) dan p-value (0.000) lebih kecil dari alpha $5 \% \quad(0.050)$. Koefisien jalur $(\beta=0.224)$ menunjukkan bahwa Kepercayaan Merek yang baik secara signifikan meningkatkan Loyalitas Merek.

\section{Temuan Penelitian}

Berdasarkan hasil penelitian yang telah dijelaskan sebelumnya, maka temuan dalam penelitian ini diperoleh bahwa keseluruhan hubungan memiliki pengaruh yang signifikan, namun sebagian dari hubungan hipotesis memiliki pengaruh positif, dan sebagian lagi memiliki pengaruh positif yang didukung oleh penelitian terdahulunya. Hal lain yang juga menjadi temuan dalam penelitian ini adalah bahwa Corporate Social Responsibility (CSR) memiliki pengaruh terhadap Citra Merek, Kepercayaan Merek dan Loyalitas Merek, survei pada masyarakat sekitar PT. Tirta Investama, Desa Keboncandi, Kecamatan Gondang Wetan, Kabupaten Pasuruan. Hal ini dilihat dari jawaban responden dari sampel yang diambil dalam penelitian ini yang mayoritas menjawab setuju terhadap pengaruh Corporate Social Responsibility (CSR) terhadap Citra Merek, Kepercayaan Merek dan Loyalitas Merek.

\section{Keterbatasan Penelitian}

Penelitian ini memiliki keterbatasan antara lain diharapkan peneliti selanjutnya, untuk melakukan penelitian secara lebih mendalam terkait cakupan wilayah penelitian yang lebih luas seperti ke Desa Tenggilis dikarenakan desa tersebut juga menerima bantuan CSR, jumlah sampel yang lebih banyak dan menambahkan beberapa variabel agar penelitian tersebut lebih kompleks seperti Citra Perusahaan, Perilaku Pembelian dan Kepuasan Pelanggan.

\section{KESIMPULAN DAN SARAN Kesimpulan}

Berdasarkan hasil analisis penelitian dan pembahasan yang telah dijelaskan pada bagian sebelumnya, maka dapat disimpulkan:

1. Penerapan program CSR oleh PT. Tirta Investama di Desa Keboncandi memiliki peran penting dalam pembentukan Citra Merek, di mana masyarakat di Desa Keboncandi mengetahui dan memperoleh program CSR PT. Tirta Investama, sehingga masyarakat merasa kehadiran perusahaan tersebut memiliki kontribusi positif bagi masyarakat sekitar. Penerapan CSR tentu sangat menguntungkan bagi perusahaan, selain mendapat kepercayaan dari masyarakat dan juga pada peningkatan Citra Merek.

2. Penerapan program CSR oleh PT. Tirta Investama di Desa Keboncandi memiliki 
peran penting dalam pembentukan Kepercayaan merek, di mana penerapan CSR membuat perusahaan tersebut lebih dikenal oleh masyarakat, sehingga tidak hanya meningkatkan citra perusahaan melainkan membangun Kepercayaan Merek, karena diyakini citra perusahaan yang baik maka memiliki merek yang baik pula hingga masyarakat percaya akan merek tersebut.

3. Penerapan program CSR oleh PT. Tirta Investama di Desa Keboncandi berpengaruh dalam membangun Loyalitas Merek, di mana manfaat CSR membuat perusahaan lebih dikenal dan lebih mudah dalam mempromosikan merek produknya kepada masyarakat, sehingga masyarakat sebagai pengguna akan terus melakukan pembelian produk Aqua hingga akhirnya merujuk pada loyalitas.

4. Citra Merek yang kuat akan mudah dalam membangun Kepercayaan Merek, di mana Citra Merek berasal dari persepsi yang tertanam dalam benak masyarakat, apabila sebuah merek yang dipilih telah sesuai dengan yang diinginkan maka masyarakat percaya merek tersebut yang terbaik.

5. Citra Merek yang baik akan mempengaruhi seseorang untuk loyal terhadap merek tersebut, di mana, sesorang tidak akan mudah untuk berpaling ke merek lain. Hal tersebut dikarenakan kualitas produk, harga yang relatif terjangkau dan produk tersebut sesuai dengan yang diinginan. Hal inilah mempengaruhi seseorang loyal terhadap suatu merek, selain karena citranya yang baik dan juga sesuai dengan keinginan.

6. Kepercayaan Merek akan merujuk pada Loyalitas Merek, karena didasari pada merek yang sesuai dengan keinginan, di mana, masyarakat selaku pengguna produk Aqua percaya terhadap produk tersebut, maka selanjutnya masyarakat akan terus menggunakan produk Aqua, sehingga hal ini yang akan membentuk loyalitas.

\section{Saran}

Berdasarkan hasil analisis penelitian Pengaruh Penerapan CSR terhadap Citra Merek, Kepercayaan Merek dan Loyalitas Merek, yang telah dijelaskan pada bagian sebelumnya, beberapa saran disampaikan sebagai berikut;

1. Berdasarkan program CSR, maka disarankan sebaiknya PT. Tirta Investama untuk menambah lebih banyak lagi program CSR yang akan diterapkan, disesuaikan dengan kebutuhan dan keadaan masyarakat, sehingga masyarakat merasa dengan kehadiran perusahaan dalam operasinya tidak hanya beorientasi pada profit, melainkan memiliki kepedulian terhadap masyarakat sekitar.

2. Berdasarkan pada Citra Merek, maka disarankan sebaiknya PT. Tirta Investama untuk terus mempertahankan Citra Merek produk Aqua tetap baik, sehingga masyarakat selaku pengguna produk selalu merasa bahwa produk Aqua merupakan produk air minum dalam kemasan (AMDK) tetap menjadi pilihan utama.

3. Berdasarkan pada Kepercayaan Merek, maka disarankan sebaiknya PT. Tirta Investama untuk terus menjaga kualitas baik dan produk terjamin aman untuk dikonsumsi, sehingga masyarakat percaya terus menggunakan produk Aqua.

4. Berdasarkan pada Loyalitas Merek, maka disarankan sebaiknya PT. Tirta Investama tetap menjaga kualitas produk, harga terjangkau dan produk disesuaikan dengan permintaan pasar, sehingga masyarakat yang sudah loyal terhadap produk Aqua tidak mudah beralih ke merek lain.

\section{DAFTAR PUSTAKA}

Aggarwal, Rashmi. 2014. Consumer Loyalty Behaviour: What is done and What else to be done. Sop Transactions on Marketing Research. Vol. 1, No. 1, pp. 1-22.

Azheri, Busyra. 2012. Corporate Social Responsibility: Dari Voluntary Menjadi Mandotory. Jakarta: Fajar Interpratama Offset.

Barnes, A. Jade. 2011. Corporate Social Responsibility and its effect on Brand Trust. Auckland University of Technology Ethics Committee (AUTEC), Thesis Unpublished.

Bastian, D.A. 2014. Analisa Pengaruh Citra Merek (Brand Image) dan Kepercayaan Merek (Brand Trust) Terhadap Loyalitas Merek (Brand Loyalty) ADES PT. Ades Alfindo Putra Setia. Jurnal Manajemen Pemasaran Petra. Vol. 2, No. 1, hal. 1-9. 
Bevan, S., N. Isles, P. Emery, and T. Hoskins. 2004. Achieving High Performance: CSR at the Heart of Business. London: The Work Foundation, Peter Runge House, 3 Carlton House Terrace.

Bhattacharya, C. B. and Sen, S. (2004). Doing Better at Doing Good: When, Why and How Consumers Respond to Corporate Social Initiatives. California Management Review. Vol. 47, No. 1, pp. 9-24.

Boonpattarakan. 2012. Competitive Capabilities of Thai Logistic Industry: Effect on Corporate Image and Performance. International Journal of Business and Management. Vol. 7, No. 5, pp. 19-30.

Broon, P. Simsic and Vrioni A. Belliu. 2001. Corporate social responsibility and cause-related marketing: an overview. International Journal of Advertising. No. 20, Vol. 2, pp. $207-$ 222.

Chaudhuri, A., and M.B Holbrook. 2001. The Chain of Effect from Brand Trust and Brand Affect to Brand Performance: The Role of Brand Loyalty. The Journal of Marketing, Vol. 65, No. 2, pp. 81-93.

Erna, Ferrina Dewi. 2008. Merek \& Psikologi Konsumen. Edisi Pertama, Cetakan Pertama. Yogyakarta : Graha Ilmu.

Fauset, Claire. 2006. What's wrong with Corporote Social Corporate. Corporate watch Report. h. 1-28.

Khan, Nida. A. 2011. A Study of Brand in the Food and Beverages Industry of Pakistan. International Journal of Business and Social Science. Vol. 2, No. 13, pp. 262-271.

Kotler, P. and Lee N. 2005. Corporate Social Responsibility: Doing the Most Good for your Company and Your Cause. New Jersey: John Wiley \& Sons.

Latif, W.B., M.A. Islam and Idris B.M. Noor. 2014. A Conceptual Framework to Build Brand Loyalty in the Modern Marketing Environment. Journal of
Asian Scientific Research. Vol. 4, No. 10, pp. 547-557.

Latif, B.W, M.A. Islam and M.B. Mohamad. 2015. Atencedents of Brand Image: A Conceptual Model. Australian Journal of Business and Economic Studies. Vol. 1, No. 1, pp. 95-100.

Lichtenstein, Drumwright and B.M. Braig. 2004. The Effect of Corporate Social Responsibility on Customer Donations to Corporate Supported Non-profits. Journal of Marketing. Vol. 68, No. 4, pp. 16-33.

Mao, Junjun. 2010. Customer Brand Loyalty. International Journal of Business and Management. Vol. 5, No. 7, pp. 213217.

Morgan, R.M and S.D. Hunt. 1994. The Commitment Trust of The Relationship Marketing. Journal of Marketing. Vol. 58, No. 3, pp. 20-38.

Odin, Y., N. Odin., and P.V. Flornce. 2015. Conceptual and operational aspect of Brand Loyalty an Empirical Investigation. Journal of Bussiness Research. Vol. 53, No. 2, pp. 75-84.

Porter, M.E. and M.R. Kramer. 2006. The Link Between Competitive Advantage and Corporate Social Responsibity. Harvard Business Review. Pp. 78-90.

Rachman, M.R., Asep Efendi dan Emir Wicaksana. 2011. Panduan Lengkap Perencanaan CSR. Bandung: Penebar Swadaya.

Sarvaiya, H and Minyu Wu. 2014. An integrated Approach for Corporate Social Responsibility and Corporate Sustainability. Published by Canadian Center of Science and Education. Vol. 10, No. 17.

Schiffman, L.G. and L.L. Kanuk. 2004. Consumer Behavior, International Edition 8 th ed. New Jersey: Pearson Prentice Hall.

Sen, S., C.B. Bhattacharya and D. Korscuhun. 2006. The Role of Corporate Social Responsibility in Strengthening Multiple Stakeholder Relationships: A Field Experiment. Journal of the 
Academy of Marketing Science. Vol. 34, No. 2, pp. 158-166.

Sengkey, Kessy F. 2015. The Influence of Brand Charateristic, Company Characteristic, and Cunsumer Brand Characteristic on Brand Loyalty at Bellagio Shoes Product in Manado. Jurnal EMBA. Vol. 3, No. 3, pp. 341351.

Sitorus, G.C. Taruli. dan Yeni Mangoting. 2014. Pengaruh Pengungkapan Corporate Social Responsibility Terhadap Profit Perusahaan Consumer Goods di Indonesia Tahun 2010-2012. Tax \& Accounting Review. Vol. 4, No. 1, pp. 1-12.

Tirta Investama. Laporan Keberlanjutan 2010. Diakses Tanggal 11 Januari 2015 dari http://tirtainvestama.com

Verma, Ankita and Kushendra Mishra. 2015. Potent Strategies to Intensify Brand Image and its Impact on Consumer Behaviour. International Conference on Science, Technology and Management. pp. 1373-1380.

Wood, Lisa. 2000. Brands and Brand Equity: Definition and Management. Management Decision. Vol. 38, No. 9, pp. 662-669.

World Business Council for Sustainable Development (WBCSD). 2002. Corporate Social Responsibility: The WBCSD's Journey. Switzerland: Conches. 